\title{
Influence of Guidance and Counselling Programmes on Secondary School Students Academic Engagement in Nyamira County, Kenya
}

\author{
Dr. James Kay \\ PhD - Kabarak University \\ Prof. James Muola \\ $\mathrm{PhD}$ - Machakos University \\ Paul C. Ondima \\ Kisii University
}

\begin{abstract}
Secondary school students are still in the age of rapid physical, social and psychological developments. These developmental changes pose a number of challenges which result to cases of maladaptive behaviour as evidenced by strikes, riots, boycotts, truancy, low self-esteem and a general lack of enthusiasm in academic activities in school, leading to poor academic performance. The current study sought to establish the influence of guidance and counselling programmes on secondary school students academic engagement. The study was guided by two theories namely; Ludwig Bertalanffy’s Systems Theory and Erickson's Psychological Development Theory. The study utilized descriptive survey design as well as ex-post facto design. The sample size of the study were 52 head teachers, 52 Deputy head teachers, 52 guidance and counselling teachers and 311 students drawn from a population of 174 head teachers, 174 Deputy head teachers, 174 Guidance and Counselling Teachers and 7740 form three students. Purposive sampling procedure was used to select public secondary schools, head teachers, Deputy head teachers, Guidance and Counselling Teachers and form three students. Stratified sampling procedure was used to group the target population into four strata based on school type and gender. Proportionate sampling procedure was used to select equal representation of respondents from each stratum of public secondary school. Random sampling procedure was used to obtain the final sample from each of the stratum. Questionnaires and interview schedules were utilized to collect data. Prior to data collection, a pilot study was conducted to ensure validity and reliability of the research instruments and using Cronbach reliability test, reliability co-efficient of $\propto=0.727$ was reported, which was considered adequate for the study. Descriptive and inferential statistics was used to analyze data. The data analysis was done with the help of computer software-statistical package for social sciences (SPSS) version 22.0. The study found out that there is a strong positive relationship $(\mathrm{R}=.575)$ between guidance and counselling services and students, academic engagement which was statistically significant $(\mathrm{P}<0.05)$. All the respondents in the study perceived school guidance and counseling programmes as effective in enhancing students academic engagement. Education stake-holders and policy makers in education who include guidance and counselling teachers, school managers, TSC personnel, Ministry of Education officials and NGOs interested in education matters may use the results of this study to strengthen, improve and maintain the guidance and counselling programme. It was recommended that guidance and counselling programme be fully supported as a matter of priority in all secondary schools to enhance students academic engagement and hence improvement in academic performance.
\end{abstract}

Keywords: Guidance and counselling programme, academic engagement Nyamira County.

DOI: $10.7176 / \mathrm{JEP} / 10-29-13$

Publication date:October $31^{\text {st }} 2019$

\subsection{Introduction}

Academic engagement which is a variable of central interest to educational psychology is an important aspect of students adaptive behaviour. The concept of academic engagement has been viewed differently by different scholars. Stoeber, Childs, Hayward \& Feast,( 2011) have viewed academic engagement as the outcome of a process in which the school provides a social context that makes students feel competent, autonomous and related. In their view academic engagement can be behavioural or emotional. Behavioural engagement is measured by effort, exertion, intensity and absorption and emotional engagement is measured by indicators such as interest, enjoyment, enthusiasm and vitality.

According to Christenson, Reschly and Wylie (2012) academic engagement captures students involvement with their studies as indicated by the amount of energy students devote to their studies as measured by such indicators as how many students enjoy their studies, how constantly they work throughout the term and how much time and energy they invest in their studies. Renshaw, Ekiund and O' Malloy (2015) regard academic engagement 
as a positive and fulfilling work-related state of mind that is characterized by vigour, dedication and absorption. Vigour characterizes the energy one invests in studying, dedication the meaning and purpose one experiences when studying and absorption the extent to which one is engrossed in one's studies.

A number of studies have established that during adolescence many secondary school students experience a decline in their academic motivation and performance. This decline is especially concerning because low engagement in school is an important risk factor for high school failure and drop out (Wang \& Fredricks, 2014; Wang 7 Degol, 2015). These studies have also found out that a supportive school environment which can partly be created by an effective guidance and counselling programme can ameliorate the developmental stresses of adolescence and protect against a decline in academic motivation and achievement.

Various reports of committees and task forces instituted in Kenya over the years have recommended the use of guidance and counselling in secondary schools to mitigate against students maladaptive behaviour Kiprop, 2012). Kamunge Report of 1986 for example assert that guidance and counselling of the youth in secondary schools is essential in the identification of their needs, of enhancing their vigour, dedication and absorption in their studies and shaping them to face the realities of life.

According to Onderi and Makori (2013) cases of maladaptive behaviour such as low academic engagement among secondary school students in Nyamira as evidenced by poor academic performance have been on an upward trend over the years. In their opinion, this state of affairs is owing to poor relationship between students, teachers and other adults in the school and a generally hostile school environment for students. They further posit that strengthening of guidance and counselling programme in Nyamira County may be a panacea for the management of students' low level of academic engagement. It is against this background that this study purposed to undertake an analysis of the influence of guidance and counselling programmes on secondary school students academic engagement in Nyamira County, Kenya.

\subsection{Statement of the Problem}

A number of secondary schools in Kenya are characterized by strikes, riots, high dropout rates, drug and substance abuse, premarital sexual activities and poor academic performance which are all symptoms of maladaptive behaviour among secondary school students. Secondary school students in Nyamira County are not an exception with regard to these maladaptive tendencies. Stakeholders have advanced a number of contributory factors to this state of affairs among which are: inappropriate role models, weak students school connectedness, poor academic engagement, low self esteem, unfriendly school environments and general systemic weaknesses in the education system. In an effort to address these challenges, the Ministry of Education has established a guidance and counselling department in every secondary school in Kenya. Inspite of this, the aforementioned cases of maladaptive behaviour in general, and poor academic engagement in particular, are still rampant in many secondary schools in Nyamira County. Unless these maladaptive behaviours are tackled, the education system will continue churning out youths with low self esteem and poor academic performance and who lack the necessary lifestyles to make them responsible individuals who will contribute to the development of society. It is therefore pertinent to ask the question, how do the secondary schools in Nyamira County use guidance and counselling programme to improve students adaptive behaviour? Considering this question, the problem of this study was to examine the influence of guidance and counselling in enhancing secondary school students academic engagement in Nyamira County.

\subsection{Research Objective}

The study was guided by the following objective:

To determine the influence of guidance and counselling programmes on students academic engagement.

\subsection{Research Hypothesis}

To investigate the influence of guidance and counselling programmes on secondary school students academic engagement in Nyamira County, the study tested the following null hypothesis:

$\mathrm{H}_{\mathrm{o}}$ There is no statistically significant relationship between guidance and counselling programmes and secondary school students' academic engagement.

\subsection{Significance of the Study}

The study is significant as it will provide valuable information regarding the influence of guidance and counselling programmes in promoting academic engagement among secondary school students. Findings from the study will shed light on how guidance and counselling can be used to enhance secondary school students academic engagement and hence an improvement in academic performance. The Ministry of Education may utilize the results of the study to come up with policies on how to strengthen guidance and counselling programmes in secondary schools through provision of adequate physical and human resources for them to play a greater role in promoting students adaptive behaviour such as academic engagement. The study may help sensitize secondary 
school administrators on the role that guidance and counselling programmes can play in creating appropriate school environments that can boost students academic engagement. Students may also benefit from the study as it will help them realize the relationship between guidance and counselling and their academic engagement and the need for them to fully utilize the programmes to their advantage. The study is also significant as it would act as an eye opener to researchers to develop more interest in searching for further knowledge on different aspects of guidance and counselling such as new approaches and techniques of guidance and counselling in a bid to make it more effective in handling different aspects of students behaviour. This will add to the pool of knowledge which is vital to the present and future generations.

\subsection{Methodology}

The study applied descriptive survey design with both qualitative and quantitative approaches. This design is defined by Frankel and Wallen (2014) as asking a large group of people questions about a particular issue. Using this design the researcher collected both qualitative and quantitative data at the same time and then integrated the information in the interpretation of the overall results (Creawell \& Clark, 2011). This design is more appropriate because it increases the overall strength of a study by enhancing the validity and trustworthy of the data. Purposive sampling procedure was used to select public secondary schools, head teachers, Deputy head teachers, guidance and counselling teachers and form three students. Stratified sampling procedure was used to group the target population into four strata abased on school type and gender. Proportionate sampling procedure was used to select equal representation of respondents from each stratum of public secondary school. In all the sample size of the study were 52 headteachers, 52 deputy head teachers, 52 guidance and counselling teachers and 311 students drawn from a population of 174 head teachers, 174 Deputy head teachers, 174 guidance and counsellng teachers and 7740 form three students.

\subsection{Instrumentation}

Open and closed ended structured self-report questionnaires and interview schedules were used in this study to elicit the required data from the respondents. Three different questionnaires were used. The first was the Head teacher/Deputy head teacher Questionnaire (HT/D/HTQ) which sought data on students maladaptive behaviour, guidance and counselling services provided in the school and the effect of such service on students academic engagement. The second questionnaire targeted guidance and counselling teachers (GCTQ) and sought to obtain data on students maladaptive behaviour, the guidance and counselling services on academic matters and role of guidance and counselling programme in promoting students in promoting students academic engagement. The third questionnaire sought to obtain data from students (SQ) on maladaptive behaviour, counselling services provided and the effect of such services on their academic engagement. For the purpose of this study, the researcher also utilized two interview schedules: one for obtaining information from Deputy/Head teachers (DHTIS) and another for eliciting data from guidance and counselling teachers (GCTIS). The interview schedules gathered information on the guidance and counselling programme and its impact on students academic engagement.

\subsubsection{Validity and Reliability of the Instruments}

Both content and face validity of the instruments was established Cronbach alpha test of validity for likert scale was used to address the question of consistency of the tool. An alpha $(\propto)$ value equal or greater than 0.7 was considered an acceptable value for the tool to be viewed as reliable (Burns \& Grove, 2007). Questionnaire for school principals had a reliability coefficient of $\propto=0.742$, Questionnaire for teacher counsellors $\propto=0.630$, and Questionnaire for students $\propto=0.809$. The overall reliability for the 30 items in the questionnaires was $\propto=0727$. Considering the threshold of 0.7 for Social Sciences (Mugenda \& Mugenda, 2009) the questionnaire was thus found to be reliable as $\propto=0.727>0.7$. Content validity was assured through collation of the structure of questionnaire and interview schedules with the research objectives and literature review. During the pilot study an analysis of the respondents reasons for their responses was carried out to establish the comprehensibility that is clarity of each item and clarity of instructions, relevance of the items and absence of biased words and phrases. Piloting therefore assisted in making necessary amendments to enhance validity of the instruments.

\subsubsection{Administration of Instruments}

The permit for the study was obtained from the National Commission for Science, Technology and Innovation (NACOSTI). The County Education Officer, Nyamira was then contacted to allow the researcher proceed to the secondary schools in the County to collect data. With the permit and an introductory letter from the researcher's university and consent from the County Education Officer, the researcher visited the sampled schools for data collection. The consent of the head teachers of the respective schools was sought and they were consulted on the day and time for the researcher to administer the instruments. During the administration of the research instruments clear instructions were given on the purpose of data collection and the ethical considerations. Only those who volunteered were included in the study. The instruments were collected the same day, as soon as the respondents completed filling them. Data that was obtained from Head/ Deputy head teachers and guidance and counselling teachers through interview was recorded by the researcher during the interview. 


\subsubsection{Data Analysis}

Data that was generated by this study was mainly quantitative. Descriptive and inferential statistics was therefore used in the data analysis. Quantitative data was analyzed using descriptive statistics like frequencies and percentages. To investigate the relationship between the variables, both regression and correlation analysis was used. Linear regression analysis was used to assess the association between the variables and the findings summarized in models and coefficient tables. For correlation analysis, Pearson correlation test was used to test the strength of association or correlation between the variables that is, how guidance and counselling programmes in secondary schools correlate with students academic engagement. Qualitative data obtained from the interviews with the Head teachers/Deputy Head teachers and teacher counselors was analyzed thematically by arranging responses according to the research objectives. The results of data analysis were presented using frequency distribution tables, pie charts and bar graphs. The data analysis was done with the aid of computer software statistical package for Social Sciences (SPSS) version 22.0. In order to make reliable inferences from the data, the statistical tests were subjected to test of significance level of 0.05 (Orodho, 2005).

\subsubsection{Ethical Considerations}

The study followed a set of standards of ethics to ensure its integrity and competence. First, the researcher ensured that the study is free of plagiarism. This was done by acknowledging all the consulted sources and citing each of them appropriately following the APA referencing style. Second, the researchers endeavored to obtain consent from respondents by informing them of the significance of the study and the need for them to participate in the study. The respondents willing to participate in the study were then asked to sign consent forms. Third, the researcher ensured that the privacy of the respondents remain anonymous and confidential. This was done by asking them not to reveal their identity on the data collection instruments. This was done by asking them not to reveal their identity on the data collection instruments. Besides, the respondents were assured that the information they volunteer would be handled carefully and with confidentiality and that it would be used only for the intended academic purpose. In addition, permission was sought from all the relevant authorities prior to data collection.

\subsection{Findings of the Study}

The study objective sought to establish the effect of guidance and counselling programme on students academic engagement. Thus data was collected to measure students academic engagement and further analysis conducted using correlation and regression to establish the relationship between guidance and counselling programmes and students academic engagement . Results were as presented in subsequent figures and tables.

\subsection{Availability and provision of Guidance and Counselling Services in the schools}

Secondary school head teachers were probed on whether they had guidance and counselling department in their schools and the guidance and counselling services offered and the providers of the services. The results were presented in figure 3.1 .

Fig. 3.1 Availability and Provision of Guidance and Counselling Services in Schools

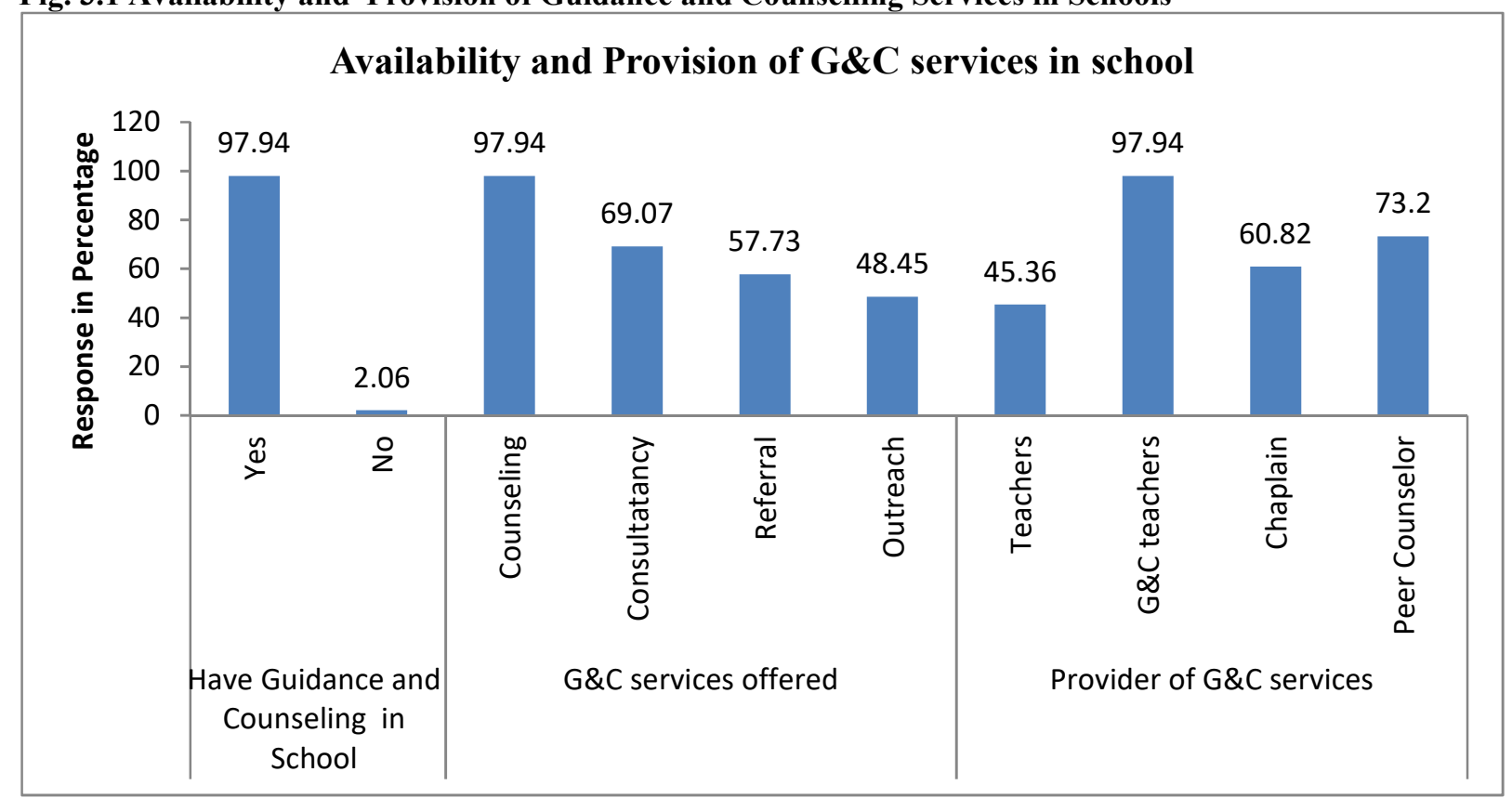

Findings in figure 3.1 indicate that $97.94 \%$ of the Head teachers who participated in the study confirmed the 
existence of guidance and counselling department in their schools. On the services offered, $97.94 \%$ indicated counselling services, $69.07 \%$ mentioned consultancy services, $57.73 \%$ indicated referral, while $48.45 \%$ indicated outreach services. This shows that guidance and counselling departments in schools offered an array of services such as counselling, consultancy, referral and outreach. The study also found out that main providers of guidance and counselling services to students were $\mathrm{G} / \mathrm{C}$ teachers as indicated by $97.94 \%$. However, there were other providers such as Chaplains, peer counsellors and other teachers in the schools as shown by $60.82 \%, 73.2 \%$ and 45.36 respectively.

\subsection{Availability of Professional Guidance and Counselling teachers in the Schools}

Respondents were also asked whether they had professional Guidance and Counselling teacher in their schools. This was imperative in order to establish the effectual provision of guidance and counselling services. The results are presented in table 3.1

Table 3.1 Availability of Professional guidance and Counselling teachers in the schools

\begin{tabular}{llcc}
\hline Variables & Response & Freq. & \% \\
\hline Have professionaG\&C teachers & Yes & 61 & 62.89 \\
& No & 36 & 37.11 \\
Level of Training of professional G\&C teacher & Certificate level & 06 & 09.84 \\
& Diploma level & 22 & 36.07 \\
& Bachelor & 29 & 47.54 \\
Experience of professional G\&C teacher & Masters level & 04 & 06.56 \\
& Less than 1 year & 05 & 08.20 \\
& $1-5$ years & 36 & 59.02 \\
\hline
\end{tabular}

As indicated in table 3.1, the study found that more than two thirds of the respondents at $62.89 \%$, confirmed that they had professional $\mathrm{G} / \mathrm{C}$ teachers while only $37.11 \%$ indicated otherwise. On level of training of professional $\mathrm{G} / \mathrm{C}$ teachers majority had undergraduate degree $(47.54 \%), 36.07 \%$ had diploma certificate in $\mathrm{G} / \mathrm{C}$, while only $9.84 \%$, and $6.56 \%$ had certificate and Masters degree respectively. This shows that most of the G/C teachers had good professional and academic qualification on $\mathrm{G} / \mathrm{C}$ hence offered effectively the $\mathrm{G} / \mathrm{C}$ services to students. The study also found that most of these teachers had long working experience as teacher counselors with majority at $59.02 \%$ indicating $1-5$ years, $32.79 \%$ indicating more than 5 years, while $8.20 \%$ had less than 1 year. Good professional experience in $\mathrm{G} / \mathrm{C}$ meant that these teachers were knowledgeable on how guidance and counselling influence students academic engagement.

\subsection{Students Response to G/C Services and its Success Rating}

Respondents were also asked to rate the response of students in their schools towards guidance and counselling and also rate the success of counselling services provided in their schools in improving students academic engagement. The results are shown in figure 3.2

Figure 3.2 Students Response to G/C services and its success rating

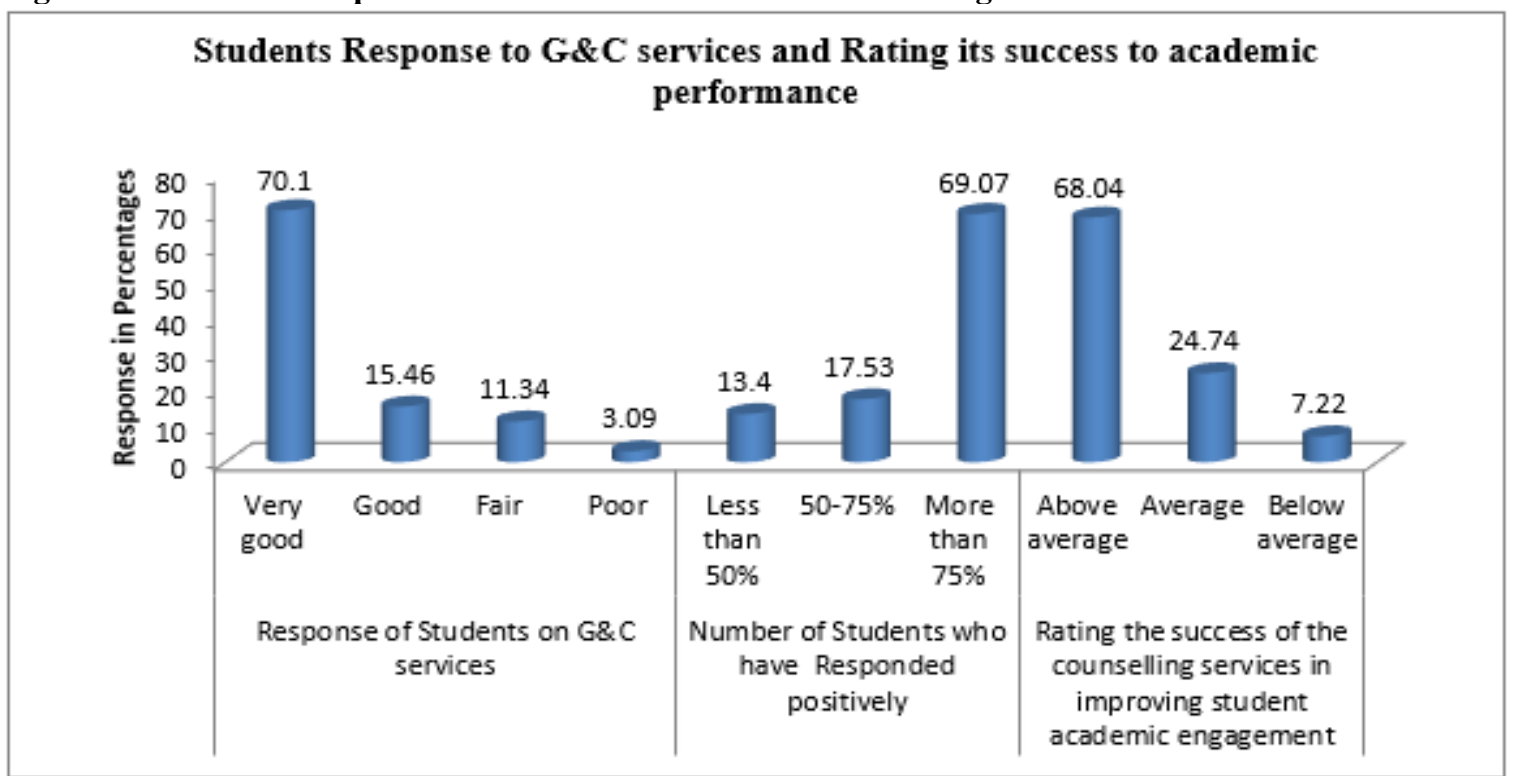

As indicated in figure 3.2, the students response to guidance and counselling was rated very high as shown 
by $70.1 \%$ while $15.46 \%$ rated the response as good. Only $11.34 \%$ and $3.09 \%$ indicated fair and poor respectively. This shows that most of the students in Nyamira County were upbeat about the G/C sessions. When probed on the number of students who had responded positively, the study found that more than two thirds at $69.07 \%$ indicated more than $75 \%$, while $17.53 \%$ indicated $50-75 \%$ as $13.4 \%$ indicated less than $50 \%$. In rating the success of the counselling services in improving students academic engagement, the study found that majority of the respondents at $68.04 \%$ rated it as above average, $24.74 \%$ indicated average while only $7.22 \%$ indicated above average. This shows that guidance and counselling sessions had a positive influence on academic engagement among students.

\subsection{Provision of Guidance and Counselling Services on Academic Matters by Teachers}

Teacher counselors were also probed on whether they provided the $\mathrm{G} / \mathrm{C}$ services on academic matters and if so which academic matters did they provide $\mathrm{G} / \mathrm{C}$ services on. The results are shown in figure 3.3.

Fig. 3.3 Provision of guidance and counselling services on academic matters by teacher counsellors

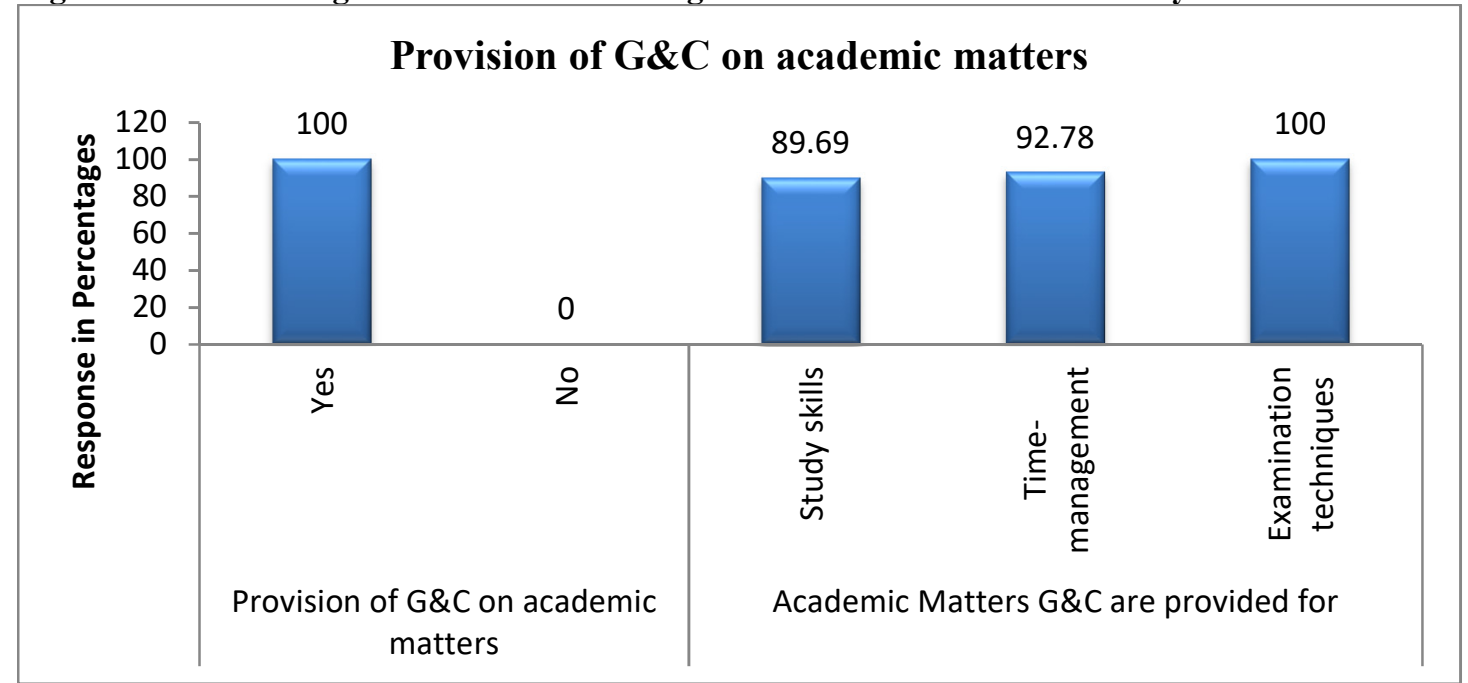

Figure 3.3 shows that the study established that all the teacher counsellors (100\%) who participated in the study revealed that they provided guidance and counselling services on academic matters to students in the various secondary schools. On academic matters they provided guidance and counselling in, $89.69 \%$ mentioned study skills, $92.78 \%$ indicated time management, while all of them $100 \%$ mentioned examination techniques. This shows that teacher counselors provided guidance and counselling services on various academic matters to improve the performance of the students.

\subsection{Various Study Skills guided by Guidance and Counselling}

Respondents were asked to indicate the various study skills they guided and counselled students in. Figure 3.4 shows the results. 
Figure 3.4 Various skills guided by Guidance and Counselling

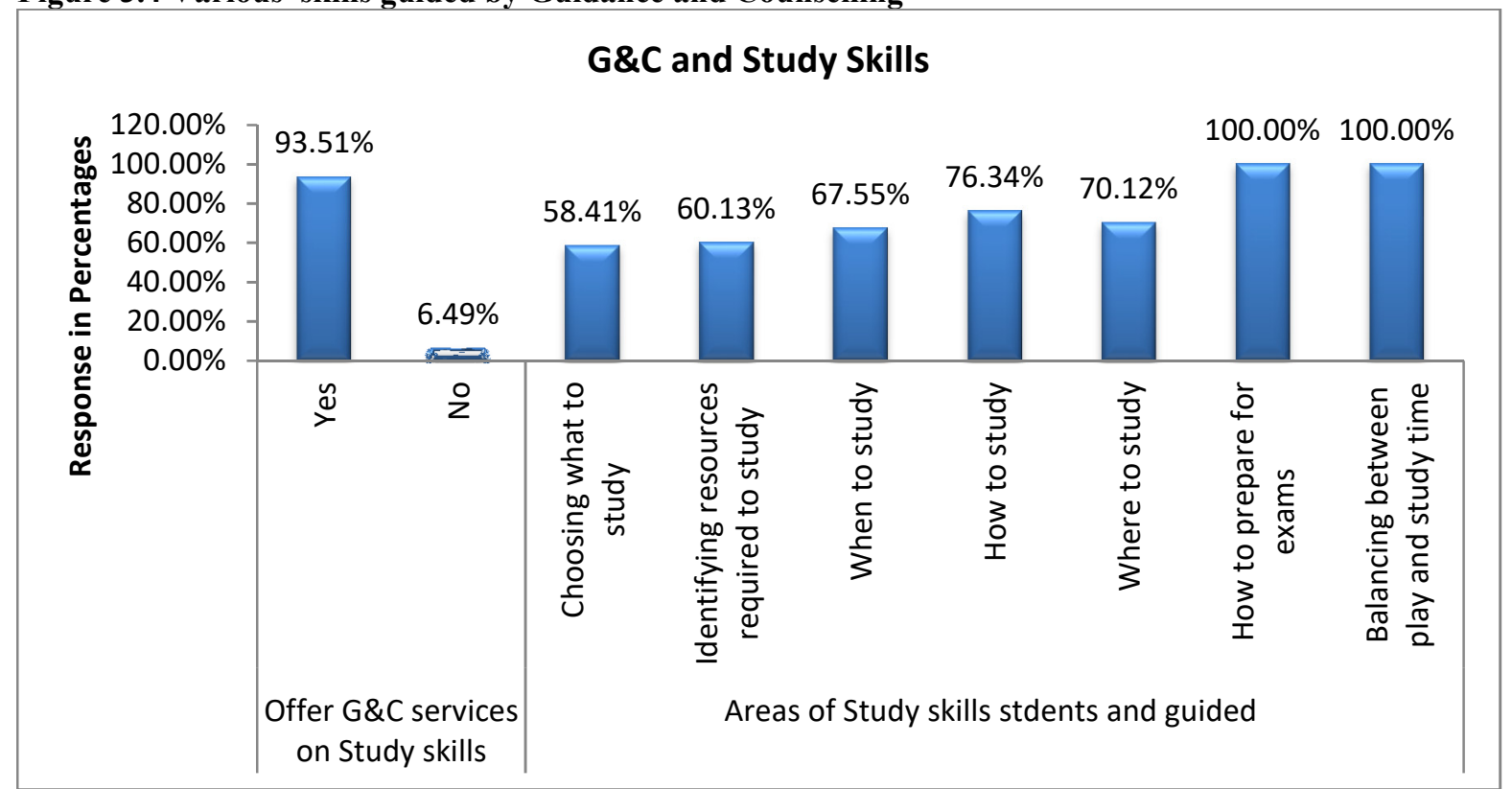

As indicated in figure 3.4, the study established that almost all the respondents at 93.51

5 agreed that they provided guidance and counselling services on study skills to their students. On various study skills, the study established that all the respondents at $100.0 \%$ indicated that they guided and counseled their students on how to prepare exams, and balancing between play and study time. Over two thirds of the respondents at $60.13 \%, 67.55 \%$ and $70.12 \%$ indicated that they guided and counseled their students on how they could identify resources required to study, when to study and where to study respectively. Over three quarters at $76.34 \%$ indicated that they guided their students on how to study.

\subsection{Role of Guidance and Counsellig services in improving Academic Engagement according to teacher counselors $(\mathrm{N}=\mathbf{4 6})$}

Guidance and counselling teachers were also probed on effects of guidance and counselling on students academic engagement which was measured using a 10-item 5-point likert scale as strongly disagree (SD), disagree (D) Neutral (N) Agree (A) and strongly Agree (SA). The data obtained was analyzed to show frequency of each response as well as percentage per item. Table 3.2 below shows the response 
Table 3.2 Role of Guidance and counselling services in improving Academic Engagement according to teacher counselors $(N=46)$

\begin{tabular}{|c|c|c|c|c|c|}
\hline Statement & $\mathbf{S A}$ & $\mathbf{A}$ & $\mathbf{N}$ & $\mathbf{D}$ & SD \\
\hline $\begin{array}{lll}\text { Improves } & \text { students } & \text { class } \\
\text { attendance } & & \end{array}$ & $\begin{array}{c}29 \\
(63.04 \%)\end{array}$ & $\begin{array}{c}7 \\
(15.22 \%)\end{array}$ & $\begin{array}{c}8 \\
(17.39 \%)\end{array}$ & $\begin{array}{c}1 \\
(2.17 \%)\end{array}$ & $\begin{array}{c}1 \\
(2.17 \%)\end{array}$ \\
\hline $\begin{array}{l}\text { Enables students manage their } \\
\text { time better }\end{array}$ & $\begin{array}{c}27 \\
(58.70 \%)\end{array}$ & $\begin{array}{c}8 \\
(17.39 \%)\end{array}$ & $\begin{array}{c}8 \\
(17.39 \%)\end{array}$ & $\begin{array}{c}2 \\
(4.35 \%)\end{array}$ & $\begin{array}{c}1 \\
(2.17 \%)\end{array}$ \\
\hline $\begin{array}{l}\text { Encourages students to seek } \\
\text { advice and help from teaching } \\
\text { staff }\end{array}$ & $\begin{array}{c}26 \\
(56.52 \%)\end{array}$ & $\begin{array}{c}10 \\
(21.74 \%)\end{array}$ & $\begin{array}{c}6 \\
(13.04 \%)\end{array}$ & $\begin{array}{c}2 \\
(4.35 \%)\end{array}$ & $\begin{array}{c}2 \\
(4.35 \%)\end{array}$ \\
\hline $\begin{array}{l}\text { Enhances students interest in } \\
\text { some subjects }\end{array}$ & $\begin{array}{c}28 \\
(60.87 \%)\end{array}$ & $\begin{array}{c}8 \\
(17.39 \%)\end{array}$ & $\begin{array}{c}7 \\
(15.22 \%)\end{array}$ & $\begin{array}{c}1 \\
(2.17 \%)\end{array}$ & $\begin{array}{c}2 \\
(4.35 \%)\end{array}$ \\
\hline Improves students study skills & $\begin{array}{c}31 \\
(67.39 \%)\end{array}$ & $\begin{array}{c}10 \\
(21.74 \%)\end{array}$ & $\begin{array}{c}4 \\
(8.70 \%)\end{array}$ & $\begin{array}{c}1 \\
(2.17 \%)\end{array}$ & $\begin{array}{c}0 \\
(0.00 \%)\end{array}$ \\
\hline $\begin{array}{l}\text { Makes each student feel part of a } \\
\text { group of students and teachers } \\
\text { committed to learning }\end{array}$ & $\begin{array}{c}27 \\
(58.70 \%)\end{array}$ & $\begin{array}{c}12 \\
(26.09 \%)\end{array}$ & $\begin{array}{c}6 \\
(13.04 \%)\end{array}$ & $\begin{array}{c}0 \\
(0.00 \%)\end{array}$ & $\begin{array}{c}1 \\
(2.17 \%)\end{array}$ \\
\hline $\begin{array}{l}\text { Enhances time spent on private } \\
\text { study }\end{array}$ & $\begin{array}{c}27 \\
(58.70 \%)\end{array}$ & $\begin{array}{c}14 \\
(30.43 \%)\end{array}$ & $\begin{array}{c}4 \\
(8.70 \%)\end{array}$ & $\begin{array}{c}1 \\
(2.17 \%)\end{array}$ & $\begin{array}{c}0 \\
(0.00 \%)\end{array}$ \\
\hline $\begin{array}{l}\text { Enhances students courage to ask } \\
\text { questions in class }\end{array}$ & $\begin{array}{c}29 \\
(63.04 \%)\end{array}$ & $\begin{array}{c}10 \\
(21.74 \%)\end{array}$ & $\begin{array}{c}6 \\
(13.04 \%)\end{array}$ & $\begin{array}{c}0 \\
(0.00 \%)\end{array}$ & $\begin{array}{c}1 \\
(2.17 \%)\end{array}$ \\
\hline $\begin{array}{l}\text { Enables students to balance } \\
\text { between play and study time }\end{array}$ & $\begin{array}{c}27 \\
(58.70 \%)\end{array}$ & $\begin{array}{c}12 \\
(26.09 \%)\end{array}$ & $\begin{array}{c}5 \\
(10.87 \%)\end{array}$ & $\begin{array}{c}1 \\
(2.17 \%)\end{array}$ & $\begin{array}{c}1 \\
(2.17 \%)\end{array}$ \\
\hline $\begin{array}{l}\text { Reduces anxiety during } \\
\text { examinations }\end{array}$ & $\begin{array}{c}25 \\
(54.35 \%)\end{array}$ & $\begin{array}{c}15 \\
(32.61 \%)\end{array}$ & $\begin{array}{c}5 \\
(10.87 \%)\end{array}$ & $\begin{array}{c}1 \\
(2.17 \%)\end{array}$ & $\begin{array}{c}0 \\
(0.00 \%)\end{array}$ \\
\hline $\begin{array}{l}\text { Leads to overall improvement in } \\
\text { academic performance }\end{array}$ & $\begin{array}{c}26 \\
(56.52 \%) \\
\end{array}$ & $\begin{array}{c}14 \\
(30.43 \%)\end{array}$ & $\begin{array}{c}3 \\
(6.52 \%) \\
\end{array}$ & $\begin{array}{c}1 \\
(2.17 \%)\end{array}$ & $\begin{array}{c}2 \\
(4.35 \%) \\
\end{array}$ \\
\hline
\end{tabular}

From the table it is clear that majority of teacher counselors at $78.26 \%$ cumulatively agreed to the statement that guidance and counselling programmes improves class attendance of students.

\subsection{Students feeling at school after receiving guidance and counselling services}

Students were asked to indicate how they felt while at school after receiving guidance and counselling services. The statements were measured using a 5-item 5-point likert scale as $1=$ strongly agree (SA) 2= agree (A) 3= Neutral, 4= Disagree (D) and 5= strongly Disagree 9SD0. The data obtained was analyzed to show frequency of each response as well as percentage per item. Item mean and standard deviation were equally computed and presented along each item as shown in table 3.3. 
Table 3.3 Students feelings towards academic matters after receiving guidance and counselling

\begin{tabular}{|c|c|c|c|c|c|}
\hline Statement & $\mathbf{S A}$ & $\mathbf{A}$ & $\mathbf{N}$ & D & SD \\
\hline I rarely skip classes & $\begin{array}{c}169 \\
(58.68 \%)\end{array}$ & $\begin{array}{c}96 \\
(33.33 \%)\end{array}$ & $\begin{array}{l}14 \\
(4.86 \%)\end{array}$ & $\begin{array}{c}5 \\
(1.74 \%)\end{array}$ & $\begin{array}{c}4 \\
(1.39 \%)\end{array}$ \\
\hline $\begin{array}{l}\text { I regularly seek advice and help from } \\
\text { teaching staff }\end{array}$ & $\begin{array}{c}157 \\
(54.51 \%)\end{array}$ & $\begin{array}{c}107 \\
(37.15 \%)\end{array}$ & $\begin{array}{c}18 \\
(6.25 \%)\end{array}$ & $\begin{array}{c}3 \\
(1.04 \%)\end{array}$ & $\begin{array}{c}3 \\
(1.04 \%)\end{array}$ \\
\hline I regularly ask questions in class & $\begin{array}{c}202 \\
(70.14 \%)\end{array}$ & $\begin{array}{c}64 \\
(22.22 \%)\end{array}$ & $\begin{array}{c}16 \\
(5.56 \%)\end{array}$ & $\begin{array}{c}2 \\
(0.69 \%)\end{array}$ & $\begin{array}{c}4 \\
(1.39 \%)\end{array}$ \\
\hline I am enthusiastic about my studies & $\begin{array}{c}153 \\
(53.13 \%)\end{array}$ & $\begin{array}{c}118 \\
(40.97 \%)\end{array}$ & $\begin{array}{c}12 \\
(4.17 \%)\end{array}$ & $\begin{array}{c}3 \\
(1.04 \%)\end{array}$ & $\begin{array}{c}2 \\
(0.69 \%)\end{array}$ \\
\hline I am proud of my studies & $\begin{array}{c}214 \\
(74.31 \%)\end{array}$ & $\begin{array}{c}51 \\
(17.71 \%)\end{array}$ & $\begin{array}{c}14 \\
(4.86 \%)\end{array}$ & $\begin{array}{c}6 \\
(2.08 \%)\end{array}$ & $\begin{array}{c}3 \\
(1.04 \%)\end{array}$ \\
\hline $\begin{array}{l}\text { When I am studying, I forget everything } \\
\text { else around me }\end{array}$ & $\begin{array}{c}177 \\
(61.46 \%)\end{array}$ & $\begin{array}{c}93 \\
(32.29 \%)\end{array}$ & $\begin{array}{l}12 \\
(4.17 \%)\end{array}$ & $\begin{array}{c}3 \\
(1.04 \%)\end{array}$ & $\begin{array}{c}3 \\
(1.04 \%)\end{array}$ \\
\hline $\begin{array}{l}\text { When I get up in the morning, I feel like } \\
\text { going to class }\end{array}$ & $\begin{array}{c}177 \\
(61.46 \%)\end{array}$ & $\begin{array}{c}88 \\
(30.56 \%)\end{array}$ & $\begin{array}{c}14 \\
(4.86 \%)\end{array}$ & $\begin{array}{c}5 \\
(1.74 \%)\end{array}$ & $\begin{array}{c}4 \\
(1.39 \%)\end{array}$ \\
\hline I can get carried away by my studying & $\begin{array}{c}183 \\
(63.54 \%)\end{array}$ & $\begin{array}{c}87 \\
(30.21 \%)\end{array}$ & $\begin{array}{l}12 \\
(4.17 \%)\end{array}$ & $\begin{array}{c}3 \\
(1.04 \%)\end{array}$ & $\begin{array}{c}3 \\
(1.04 \%)\end{array}$ \\
\hline $\begin{array}{l}\text { I find my studies to be full of meaning and } \\
\text { purpose }\end{array}$ & $\begin{array}{c}173 \\
(60.07 \%)\end{array}$ & $\begin{array}{c}96 \\
(33.33 \%)\end{array}$ & $\begin{array}{l}12 \\
(4.17 \%)\end{array}$ & $\begin{array}{c}2 \\
(0.69 \%)\end{array}$ & $\begin{array}{c}5 \\
(1.74 \%)\end{array}$ \\
\hline $\begin{array}{l}\text { I regularly borrow books from the school } \\
\text { library }\end{array}$ & $\begin{array}{c}180 \\
(62.50 \%)\end{array}$ & $\begin{array}{c}85 \\
(29.51 \%)\end{array}$ & $\begin{array}{c}15 \\
(5.21 \%)\end{array}$ & $\begin{array}{c}5 \\
(1.74 \%)\end{array}$ & $\begin{array}{c}3 \\
(1.04 \%)\end{array}$ \\
\hline $\begin{array}{l}\text { I am strategic about the way I manage my } \\
\text { academic workload }\end{array}$ & $\begin{array}{c}197 \\
(68.40 \%)\end{array}$ & $\begin{array}{c}70 \\
(24.31 \%)\end{array}$ & $\begin{array}{c}10 \\
(3.47 \%)\end{array}$ & $\begin{array}{c}6 \\
(2.08 \%)\end{array}$ & $\begin{array}{c}5 \\
(1.74 \%)\end{array}$ \\
\hline $\begin{array}{l}\text { I usually come to class having completed } \\
\text { my assignments }\end{array}$ & $\begin{array}{c}192 \\
(66.67 \%)\end{array}$ & $\begin{array}{c}74 \\
(25.69 \%)\end{array}$ & $\begin{array}{l}11 \\
(3.82 \%)\end{array}$ & $\begin{array}{c}7 \\
(2.43 \%)\end{array}$ & $\begin{array}{c}4 \\
(1.39 \%)\end{array}$ \\
\hline I regularly make class presentations & $\begin{array}{c}151 \\
(52.43 \%)\end{array}$ & $\begin{array}{c}117 \\
(40.63 \%)\end{array}$ & $\begin{array}{c}12 \\
94.17 \%)\end{array}$ & $\begin{array}{c}5 \\
(1.74 \%)\end{array}$ & $\begin{array}{c}3 \\
(1.04 \%)\end{array}$ \\
\hline I find my grades improving & $\begin{array}{c}216 \\
(75.00 \%)\end{array}$ & $\begin{array}{c}40 \\
(13.89 \%)\end{array}$ & $\begin{array}{c}18 \\
(6.25 \%)\end{array}$ & $\begin{array}{c}8 \\
(2.78 \%)\end{array}$ & $\begin{array}{c}6 \\
(2.08 \%)\end{array}$ \\
\hline
\end{tabular}

According to the findings in table 3.3, majority of the students $92.01 \%$ revealed that they rarely skipped diseases after receiving guidance and counselling services in their schools. Only $3.13 \%$ indicated otherwise as $14(4.86 \%)$ remained neutral. This implies that guidance and counselling programmes encouraged class attendance as teacher-student relationship improved. Infact, $91.6 \%$ of the students confirmed that they regularly sought advice and help from their teaching staff. The study also found that most of the students were enthusiastic about their studies and were proud about their studies too as shown by $94.1 \%$ and $92.02 \%$ respectively. Over $1.46 \%$ of the respondents also strongly agreed that whenever they were studying, they forget everything else around them and every morning they get up, they were encouraged to go to class. Indeed, every morning, they get carried away by their studies as shown by $3.54 \%$ of the respondents. Further, $60.07 \%$ strongly supported the statement that they find their studies to be full of meaning and purpose. The study also found that over two thirds of the respondents strongly agreed with the statements that they regularly borrowed books from the school library, were strategic about the way they managed their academic workload and usually came to class having completed their assignments as shown by $2.50 \%, 68.40 \%$ and .7\% respectively. Majority at $91.1 \%$ cumulatively indicated that they regularly made class presentations, while only $2.78 \%$ indicated otherwise as $12(4.17)$ remained neutral on this statement. Generally the grades of the students were indicated by the students to be improving as shown by three quarters of the respondents at $75.0 \%$.

Similarly, during the interview sessions with the school Principals/Deputy Principals, it was found that guidance and counselling on educational matters is normally carried out to develop skills that assist students as they learn. One of the school deputy principals had this to offer,

Guidance and counselling for secondary students is designed to address the physical, emotional, social and academic difficulties of adolescents. By resolving this, students understand their learning strengths and weaknesses 
hence improve their study habits leading to better scores. The guidance programme promotes academic, educational, personal, social and career development fostering positive attitude towards school, learning and work resulting to improved academic achievement. The counsellor, through classroom guidance activities and individual and group counselling, can assist and encourage student sin applying effective study skills, setting goals, learning effectively, and gaining test-taking skills. Counsellors may also focus on note taking, time management, memory techniques, relaxation techniques, overcoming test anxiety, and developing listening skills. (interview, School Deputy Principal, 5, 15/5/2018).

A study on the effects of counselling on classroom performance found that the underachieving students who received counselling improved significantly on the self rating scale of classroom behaviour in mathematics and language grades (Gerler, Kinney \& Anderson, 2015) as counseling decreases classroom disturbances. It supports teachers in classroom in order to enable them provide quality instruction designed to assist students in achieving high standards. Students in schools that provides counselling services indicated that the classes were less likely to be interrupted by other students and that their peers behaved better in school. In the same line of thought, one of the teacher counselors had this to say,

Academic counselling aims at assisting pupils to make the most of their educational opportunities. These means offering pupils the assistance that will make them become cultivated individuals and at the same time preparing them for confident participation in life activities which will be socially useful and personally satisfying. Academic counselling is for students of all categories. The gifted ones are given academic counselling to enable them realize their capacities and the need to do more. Dull students are also helped to convince themselves of what they can do to perform well in school. Further, children who are physically challenged are helped to realize their potentialities for a happier life.

(Interview, Teacher counsellor, 8, 17/5/2018)

Wang and Degol (2015) also found that student counselling improves school attendance, school behaviour, enhances student achievement and improves students levels of self-esteem and attitude towards school. Similarly Dary and Pickerel (2013) argues that guidance and couneslling plays a vital role in removing the educational, personal, social, mental, emotional and other similar problems of the students by creating the environment for guiding and counselling to be approachable. Thus students with access to counselling programs are more positive, hence great feeling of belonging, feeling safe in their school and have high expectations.

\subsection{Relationship between guidance and counselling services and students academic engagement 4.1 Hypothesis Testing \\ Null Hypothesis}

$\mathrm{H}_{0}$ :There is no statistically significant relationship between guidance and counselling services and secondary school students academic engagement.

To establish whether there was any significant relationship between guidance and counselling services and secondary school students academic engagement, a pearson correlation analysis was conducted between the two variables. Since data for guidance and counselling services and students academic engagement among form three students were measured on ordinal Likert level for each item, it was important to obtain continuous data to facilitate performance of correlation for each of the two scales. The corresponding scores for each respondent were used as data points for the 288 students participants.

The null hypothesis was to be tested at 0.05 significance/alpha level $(\propto)$. The test statistic is converted to a conditional probability called a $\rho$-value. If $\rho<\propto$ the null hypothesis is rejected, meaning that the observed difference is significant, that is, not due to chance. However, if the $\rho$-value will be greater than 0.05 (i.e $\rho>$ $\propto)$, the null hypothesis will not be rejected (we fail to reject the null hypothesis), meaning the observed difference between the variables is not significant. The correlation out put is presented in table 3.4.

Table 3.4 Correlation output for guidance and counselling services and students' academic engagement

\begin{tabular}{|c|c|c|c|c|}
\hline & & & $\begin{array}{c}\text { Guidance and } \\
\text { Counseling }\end{array}$ & $\begin{array}{l}\text { Students' } \\
\text { Engagement }\end{array}$ \\
\hline \multirow{3}{*}{$\begin{array}{l}\text { Guidance } \\
\text { Counseling }\end{array}$} & \multirow{3}{*}{ and } & Pearson Correlation & 1 & $.575^{* *}$ \\
\hline & & Sig. (2-tailed) & & .000 \\
\hline & & $\mathrm{N}$ & 288 & 288 \\
\hline \multirow{2}{*}{$\begin{array}{l}\text { Students' } \\
\text { Engagement }\end{array}$} & \multirow[t]{2}{*}{ Academic } & $\begin{array}{l}\text { Pearson Correlation } \\
\text { Sig. (2-tailed) }\end{array}$ & $\begin{array}{l}.575^{* *} \\
.000\end{array}$ & 1 \\
\hline & & $\mathrm{N}$ & 288 & 288 \\
\hline
\end{tabular}

The findings in table 3.4 show that there is a strong positive relationship ( $\mathrm{R}=0.575)$ between guidance and counselling services and students academic engagement which was statistically significant $(\rho<0.05)$. Since the significance ( $\rho$ value) of Levene's test $(0.003)$ is less than $\propto$ level $(0.05)$ then we reject the null hypothesis, that the variances of the two groups are equal, implying that the variances are not equal. The findings show that $\rho-$ value is less than the significance level $(0.05)$, that is $0.00<0.05$. The null hypothesis is therefore rejected and the 
alternative hypothesis accepted. This implies that statistically as more guidance and counselling services are conducted in schools, academic engagement among the students also increases. Sink and Stroh (2013) found that early elementary aged students who attend the same school for three or more years where comprehensive counselling programmes were in place performed better academically. In addition, students who remained in the same school for multiple years with a fully implemented school counselling programme earned higher achievement test scores than those who attended schools where no such programmes were in place.

\subsection{Regression Analysis}

To determine the effect of guidance and counselling services on students academic engagement among the form three students, regression analysis was conducted between the variables. Data collected was converted to continuous data by summating the individual item scores in the scale for each respondent. Data obtained from each respondent provided 288 data points. The regression output is presented in table 3.5.

Table 3.5 Regression output for Guidance and Counselling Services on students Academic Engagement

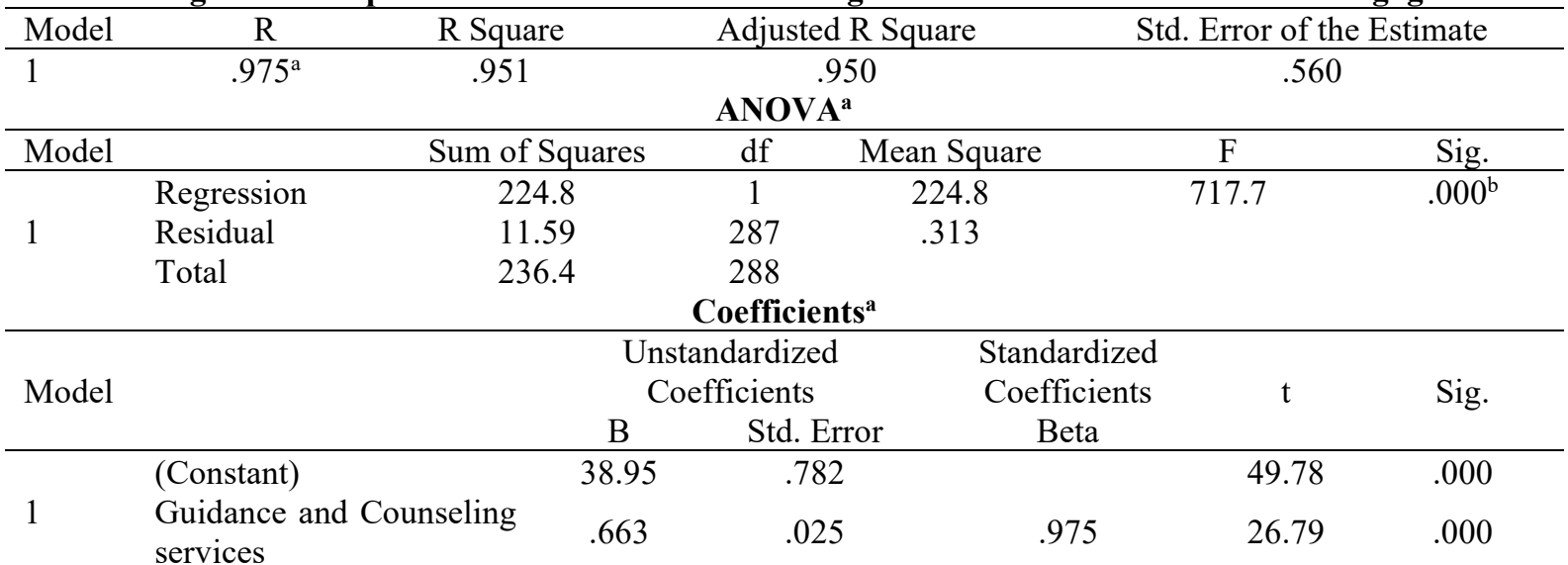

The study found that guidance and counselling services explained upto $95.1 \%(\mathrm{R}$ square $=.951)$ of the variance in the students academic engagement. The model was found to be statistically significant as $\mathrm{F}(1,288)$ $=717.7[\rho<0.5]$. Thus from regression, guidance and counselling is able to account for $95.1 \%$ of variance in the students academic engagement. The variables were modeled to be connected by the linear regression equation in the form:

$\mathrm{Y}=\mathrm{B}_{0}+\mathrm{B}_{1} \mathrm{X}_{1}+\epsilon$

Where $\mathrm{Y}$ is students academic engagement, $\mathrm{B}_{0}$ is coefficient of constant term, $\mathrm{B}_{1}$ is coefficient of guidance and counselling services, $X_{1}$ is guidance and counselling services and $\in$ is error term.

Thus replacing the coefficient of regression the formula becomes:

$\mathrm{Y}=38.95+0.663 \mathrm{X}_{1}$

This shows that, when guidance and counselling services change by one positive unit, students academic engagement also significantly increases by 0.663 . Thus guidance and counselling services positively affects students academic engagement to a magnitude of 0.663 as indicated by the main effects.

\subsection{Discussion}

The purpose of the study was to assess the influence of guidance and counselling programme in promoting secondary school students academic engagement in Nyamira County, Kenya. The study found that all the 46 teacher counsellors $(100 \%)$ who participated in the study provided the guidance and counselling services on academic matters to students in their various secondary schools. On the academic matters they provided guidance and counselling in, $89.69 \%$ mentioned study skills, $92.78 \%$ indicated time management, while all of them mentioned examination techniques. Almost all the respondents at $93.51 \%$ agreed that they provided guidance and counselling services on study skills to their students. On different skills, the study established that all the respondents at $100.0 \%$ indicated that they guided their students on how to prepare for exams, and balancing between play and study time. Over two thirds of the respondents at $60.13 \%, 67.55 \%$ and $70.12 \%$ indicated that they guided and counseled their students on how they could identify resources required for study, when to study and where to study respectively. Over three quarters at $76.34 \%$ indicated that they guided their students on how to study. The findings show that there is a strong positive relationship $(\mathrm{r}=.575)$ between guidance and counselling services and students' academic engagement which was statistically significant $(\rho<0.05)$. This implies that statistically as more guidance and counselling services are conducted in schools, academic engagement among the students also increases. Thus the null hypothesis $\left(\mathrm{H}_{0}\right)$ of: There is no significant relationship between guidance and counselling services and secondary school students' academic engagement was rejected. 


\subsection{Conclusions}

Based on the findings of this study which have been discussed in the foregoing sections, the following conclusions have been drawn.

- The guidance and counselling programme reduced skipping of classes by students, improved students use of the library, students study skills and enhanced academic achievement.

- The guidance and counselling programmes on academic matters in secondary schools were based on an array of academic issues such as study skills, time management, examination techniques and when and how to study.

- The teacher-student relationship is improved through the guidance and counselling services provided to secondary school students. This has in turn enhanced class attendance and more teacher consultation by secondary school students.

- Guidance and counselling programme is designed to address the physical, emotional, social and academic difficulties of adolescents which enables students to understand their learning strengths and weaknesses hence improving their study habits leading to better scores.

- Secondary school students enthusiasm about their studies and attitude towards school was enhanced through guidance and counselling programme. This significantly improved their classroom behaviour and their academic performance.

- Secondary school students with access to guidance and counselling services on academic matters are more positive, feel safe, have a great feeling of belonging and a higher sense of expectation and this increases their academic achievement.

- Guidance and counselling on academic matters was targeted at secondary school students of all categories. The gifted ones are given counselling to enable them realize their capabilities and the need for them to do even better. The underachievers are helped to understand their weaknesses and what they can do to perform better.

- Students in schools that provide guidance and counselling on academic matters behaved well in the classroom and the classes were less likely to be disturbed. This enable teachers to provide quality instruction to assist students in achieving high academic standards.

\subsection{Recommendations}

In view of the fact that guidance and counselling programme play an important role in enhancing secondary school students academic engagement as indicated in the study findings, the following recommendations are made for policy and practice.

- All teachers in secondary schools need to understand in depth the concept of guidance and counselling in the school setting and how it can be used to improve academic performance.

- The Ministry of Education and other stakeholders should organize regular seminars and workshops to offer continuing education on guidance and counselling. This will equip the teacher counselors with latest theories and techniques of counselling to make them more effective in the provision of guidance and counselling services.

- The government through the Ministry of education and the Teachers Service Commission should deploy more teacher counselors in schools to effectively tackle the social and academic challenges facing the students.

- The guidance and counselling programmes in the schools should be strengthened through equipping the guidance and counselling departments and providing more moral and financial support.

- School administrators should endeavour to strengthen the peer counselling programme in secondary schools.

\section{Suggestions for further Research}

The researchers recommend future research in the following aspects:-

- Impact of teacher-student relationship on students academic engagement.

- Influence of group counselling on students engagement.

- Role of parents in enhancing students academic engagement.

- Role of guidance and counselling in promoting secondary school students study skills.

- The role of guidance and counselling in promoting secondary school students time management skills.

\section{References}

Carey, J., Harrington, K. Martin, I. \& Hoffman, D (2012) A statewide evaluation of the outcomes of the implementation of ASCA National model school counselling programmes in rural and urban Nebraska high 
schools. Professional school counselling, 16, 100-107.

Christenson, S.L Reschly, A.L \& Wylie, C. (2012). Handbook of Research on student engagement. New York. Springer.

Creswell. J.W \& Clark, P.V (2011) Designing and conducting mixed methods Research. Sage Handbook. Sage.

Dary, T. \& Pickerel, T (2013) School clinical: practices for implementation and sustainability. Journal of climate practice Briefs. Vol 1(13) pp. 151-156

Frankel, J.R \& Wallen, E.N (2014). How to Design and Evaluate Research in Education. San Francisco University. San Francisco.

Gerler, E.R \& Anderson, R.E (2015) The effects of classroom guidance on children's success in school. Journal of counselling and development. JCD 65 (2): 78-81.

Kiprop C. (2012) Approaches to management of Discipline in secondary schools in Kenya. International Journal of Research in Management issues. Vol. 2: 210-216.

Machingambi, S. (2012) How do schools push students out of school. A case study of two rural secondary schools in Masvingo District of Zimbabwe. Journal of social science, vol 30(1), 55-63

Onderi, H. \& Makori A. (2013) An evaluation of secondary school Principals' perception of learning outcomes in free secondary education in Kenya. African Education Research Journal. Vol. 1(3) pp. 171-182.

Shocket, I.M \& Smith, C (2011) A prospective study investigating the links among classroom environment, school connectedness, and depressive symptoms in adolescents. Journal of psychology in the schools. Vol 51(5).

Sink, C.A \& Stroh, H.R (2013) Practical significance. The use effect sizes in school counselling.

Stoeber, J. Childs J.H Hayward,, JA \& Feast, AR (2011) Passion and motivation for studying: predicting academic engagement and burnout in university students. Educational psychology. Vol. 31 (4), 513-528.

Wang, S.C \& Fredricks, J.A (2014) The reciprocal links between school engagement, youth problem behaviours and school dropout during adolescence. Child Development. 85, 722-737.

Wang M.T \& Degol K. (2015) School climate, A Review of the construct, measurement and impact on student soutcome.

Whinston S.C Tai, W.I, Raharda, D \& Elder, K (2011) School counselling outcome. A mala analytic examination of interventions. Journal of counselling and Development. 89, 37-55. 